\title{
Regulation of seasonal variability of aminopeptidase activities in surface and bottom waters of Uranouchi Inlet, Japan
}

\author{
Arun B. Patel, Kimio Fukami * , Toshitaka Nishijima \\ Faculty of Agriculture, Kochi University, Otsu 200 Monobe, Nankoku 783-8502, Japan
}

\begin{abstract}
The potential aminopeptidase activity (APA) vis-à-vis important ecological parameters of surface and bottom waters of Uranouchi Inlet (Japan), a semi-enclosed eutrophic coastal ecosystem, were studied on a weekly to biweekly basis from mid-August 1996 to early November 1997. The aim of this study was to investigate the main factors regulating the annual and seasonal dynamics of APA in the inlet. APA was estimated in short-term incubations as the $V_{\max }$ of the rate of enzymatic hydrolysis of a fluorophore 7-L-leucyl-4-methyl couomarinylamide under conditions close to those of in situ. The water column structure at the study site changed considerably during the study period as the ecological parameters such as temperature, dissolved oxygen (DO), nutrient contents, and bacterial abundance exhibited pronounced seasonal stratification (May to September). When the water column was mixed (October to March), surface and bottom waters possessed similar A.PA. But when the water column became stratified, pronounced differences became apparent, with surface water showing considerably higher APA. On extreme days, surface water possessed as much as -20 times higher APA than that of bottom water. Thus, APA of surface water demonstrated strong seasonality and varied by almost 40 -fold compared to that of bottom water, which varied only about 12 -fold during the study period. Notably, bacterial abundances of both waters showed limited seasonality and varied only $\sim 3$-fold during the same period. These results imply that changes in APA are not merely a function of bacterial abundance but rather more of per-cell activity. On an annual basis, APA in both waters were positively correlated ( $p<0.001)$ with temperature and bacterial abundance, and negatively correlated with salinity ( $p<0.001$ for surface and $p<0.01$ for bottom water) but were not correlated ( $p>0.05)$ with DO, chlorophyll $a$ ( $p<0.05$; only for surface water), inorganic or organic forms of nitrogen (DIN, DON) or inorganic phosphorous (DIP) contents. Furthermore, when the water column was mixed, APA correlated strongly with temperature $(\mathrm{p}<0.001 ; \mathrm{r}=0.87)$, and marginally $(\mathrm{p}<0.05)$ with DIN $(\mathrm{r}=0.43)$ and DIP $(r=0.40)$ content but not with $\mathrm{DO}(p>0.05)$ content. In contrast, when the water column became stratified, A.PA correlated only marginally with temperature $(0.01<p<0.05 ; \mathrm{r}=0.33)$ but strongly with DO $(p<0.001 ; r=0.73)$, and negatively $(p<0.001)$ with DIN $(r=-0.61)$ and DIP $(r=-0.70)$ content. DON content did not show any correlation $(\mathrm{p}>0.05)$ with APA regardless of whether the water column was mixed or stratified. These correlations suggest that temperature played a critical role in regulating the APA when the water column was mixed (October to March), and DO or inorganic nutrient contents (May to September) when the water column was stratified.
\end{abstract}

KEY WORDS: Aminopeptidase activity - Thermal stratification - Water column structure - Bacterial abundance $\cdot$ Per-cell activity

\section{INTRODUCTION}

The rapid development of intensive aquaculture practices in coastal areas over the past decade has led to excessive discharge of uneaten feed and feces into

\footnotetext{
•Corresponding author: E-mail: fukami@cc.kochi-u.ac.jp
}

the surrounding environments (Johnsen et al. 1993). The resulting organic enrichment of the receiving environments has been found to have serious ecological as well as economical impacts (Gowen et al. 1990, Weston 1990, Shpigel et al. 1993). In some cases, it has even directly affected the farming by causing mass mortalities of cultivated animals (Johnsen et al. 1993). In order to ensure clean coastal environments and sus- 
tainable farming, these allochthonous organic materials must be decomposed and utilized by the microflora or recycled within the recipient ecosystems.

Heterotrophic bacteria play a central role in the utilization or recycling of organic materials in marine ecosystems (Sepers 1977, Jackson et al. 1995). However, the majority of organic matter in aquatic environments is of polymeric type (Romankevich 1984, Münster \& Chróst 1990) and are too large to be transported directly into the bacterial cells and must undergo enzymatic hydrolysis extracellularly to be available for bacterial metabolism (King 1986, Chróst 1991). This extracellular hydrolytic step has been acknowledged to be the rate-limiting step (Hoppe 1983, Chróst 1990, MeyerReil 1991).

Polymeric nitrogenous compounds such as proteins and peptides constitute major components of the effluents from intensive aquaculture farms which characteristically use high protein diets (McCaig et al. 1999). Hence, it is important to quantify their extracellular hydrolysis in the recipient ecosystems, and also to know the main environmental factors which regulate their hydrolytic rate. Although in recent years several studies have been undertaken to estimate the rate of enzymatic hydrolysis of protein in a variety of ecosystems (Hollibaugh \& Azam 1983, Somville \& Billen 1983, Lovejoy et al. 1996), relationships between the hydrolytic rates and ecological factors are still not clear (Rosso \& Azam 1987). It is also important to consider that controlling environmental factors may be seasonspecific, shifting with the changing of seasons especially in regions which experience considerable alterations in the environmental conditions within a year. For instance, Shiah \& Ducklow (1994) observed that growth of bacteria is controlled by temperature during nonsummer periods, but other factors assume greater importance in summer. Furthermore, formation of thermal or density stratification in temperate or subtropical regions may affect the hydrolytic rates of surface and bottom waters in different manners by compartmentalizing the water column with regard to microbial communities as well as physicochemical parameters.

We studied the seasonal dynamics of aminopeptidase activity (APA), a measure of extracellular hydrolysis of protein, in surface and bottom waters, and sediment of Uranouchi Inlet (Japan), simultaneously. The study site is a semi-enclosed eutrophic coastal ecosystem with only limited water exchange (Fukami et al. 1991b). During summer, serious algal blooms and pronounced thermal stratification leading to oxygen-rich surface and oxygen-deficient bottom environments have also been reported (Fukami et al. 1996). In the present paper, we describe fluctuations in the APA in surface and bottom waters of the inlet during an annual cycle, and investigate correlations between APA and ecological parameters such as bacterial abundance, temperature, dissolved oxygen (DO), salinity, chlorophyll a (chl a) and nutrient contents. We were also especially interested in identifying environmental factors which regulate the variations in APA exclusively during stratified or mixed homogenous water columns.

\section{MATERIALS AND METHODS}

Study site and sample collection. The sampling site, Mitsumatsu sampling station, is located in the highly eutrophic portion of the Uranouchi Inlet of Kochi prefecture in Japan (Fig. 1). The description of the site can be found elsewhere (Fukami et al. 1991b, 1996). In short, near and around the sampling station, intensive cage culture of yellow tail and red sea bream is widely practiced. These cages discharge considerable amounts of effluents into the inlet, leading to eutrophication of the site. Average depth near the sampling station is 16 to $17 \mathrm{~m}$.

Samples of surface $(2 \mathrm{~m})$ and bottom $(16 \mathrm{~m})$ waters were collected on a weekly to biweekly basis using Kitahara (1 l) or Niskin (5 l) water samplers. Samples were transferred into acid-washed glass bottles while ensuring minimum oxygen contamination, and were transported to the laboratory within 1 to $2 \mathrm{~h}$ of collection under cool and dark conditions.

Measurement of physical and biochemical parameters. A CTD system of the Ocean Seven meter (Idro-

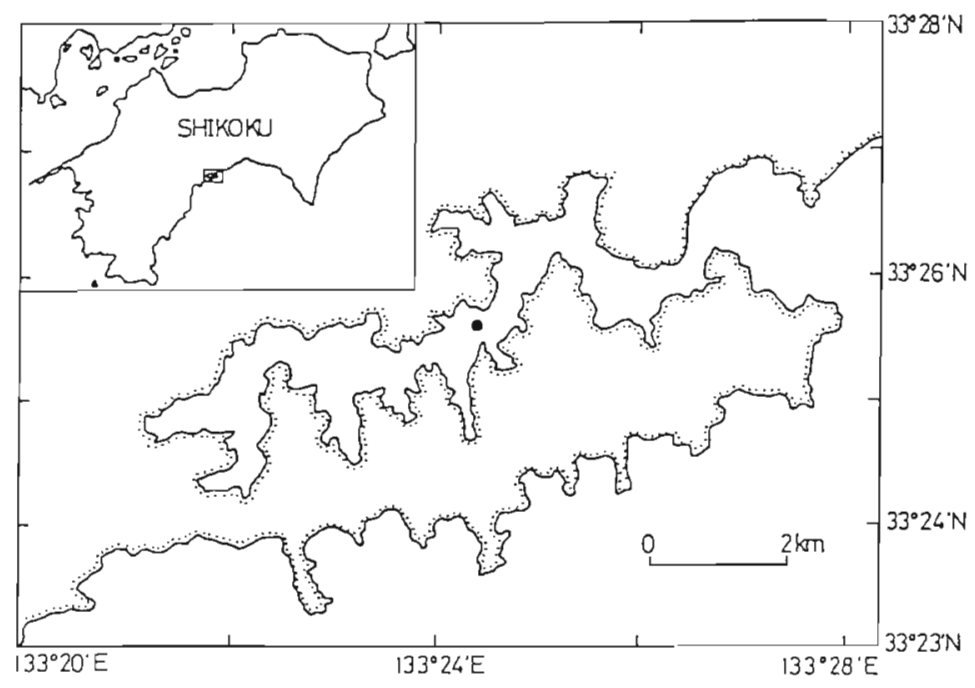

Fig. 1. Location of the sampling station in Uranouchi Inlet of Kochi prefecture, Japan 
naut, model no. $301 \mathrm{~S}$ ) was used to measure in situ temperature, $\mathrm{DO}, \mathrm{pH}$, salinity, and redox potential of the water column at the sampling site.

For nutrient analyses such as nitrogen and phosphorus, subsamples of waters were filtered through $\mathrm{GF} / \mathrm{F}$ glass fiber filters (precombusted at $450^{\circ} \mathrm{C}$ for $3 \mathrm{~h}$ ) and filtrates were stored at $-20^{\circ} \mathrm{C}$ until analyzed. The inorganic forms of dissolved nitrogen (DIN) $\left(\mathrm{NH}_{4}, \mathrm{NO}_{2}\right.$ and $\left.\mathrm{NO}_{3}\right)$, and phosphorus (DIP) $\left(\mathrm{PO}_{4}\right)$ were determined using an automatic analyzer (Bran+Luebbe TRAACS 800). Total dissolved nitrogen (TDN) concentrations were measured using Sumigraph N-200 (Shimadzu Corp.). Dissolved organic nitrogen (DON) contents of the waters were calculated by subtracting DIN from TDN.

The chl a concentrations in waters were measured utilizing a spectrophotometric method (APHA 1985). Bacterial abundances were determined by direct counting under epifluorescence microscopy using DAPI (4', 6-diamidino-2-phenylindole dihydrochloride) as staining reagent (Porter \& Feig 1980, Fukami et al. 1991a).

Estimation of APA. The APA in surface and bottom waters was estimated utilizing the enzyme assays of a fluorogenic substrate analog, 7-L-leucyl-4-methyl coumarinylamide (Leu-MCA), which gives rise to a highly fluorescent compound, 7-amino-4-methylcoumarin (AMC), when the peptide bond is hydrolyzed (Saifuku et al. 1978). This substrate was selected owing to its practical availability, high sensitivity and relatively short incubation period required (Hoppe 1983). This substrate has been used extensively to measure the aminopeptidase activities in a variety of aquatic ecosystems (Hoppe et al 1988, Chróst 1991, Poremba 1995). The assays were conducted with in situ waters and multiple concentrations of substrate analog (Meyer-Reil 1990) $(2.5,5.0,10.0,20.0$ and $40.0 \mu \mathrm{M}$ final concentration) at in situ bottom water temperature. Though temperatures of surface water were slightly different than those of bottom water during stratified periods, for simplicity, assays for both waters were conducted at the same temperature (bottom water temperature). Incubation started as soon as possible (within 2 to $3 \mathrm{~h}$ of sampling) to minimize bottle effect (Venerich et al. 1977), and the incubation period was kept relatively short (under $45 \mathrm{~min}$ ) to attenuate nonlinear metabolic responses (Goldman et al. 1981). Assays were always conducted in duplicates and no shaking or artificial illumination was provided during the incubation.

The aliquots $(15 \mathrm{ml})$ of water samples were transferred into acid-washed glass incubation bottles and were acclimated for 20 min at in situ temperature in a water bath. Thereafter, an enzyme reaction was started by adding the above-mentioned multiple concentrations of substrates into the incubation bottles. Time series of the activity response for each substrate concen- tration was conducted by stopping the enzyme reaction at the desired time points. The reaction was stopped by introducing a subsample of $4.0 \mathrm{ml}$ from the relevant incubation bottle into a test tube which contained $0.32 \mathrm{ml}$ of reaction stopper (buffered neutral formalin:1 $\mathrm{M}$ trishydroxymethyl aminomethane as $1: 3 ; \mathrm{v} / \mathrm{v}$ ). Zero-time point for each substrate concentration was achieved by fixing $4.0 \mathrm{ml}$ of water samples with reaction stopper prior to addition of the substrate in a separate set of test tubes. At least 3 time points, in addition to the zero-time point, were obtained for each substrate concentration.

Following incubation, the test tubes were vortexed to release any AMC adsorbed to the suspended particles, and then centrifuged to get a clear solution. Fluorescence in the supernatant was read using a spectro-fluorophotometer (Shimadzu RF-500) at $365 \mathrm{~nm}$ excitation and $440 \mathrm{~nm}$ emission wavelengths. The spectrofluorophotometer was calibrated against standard chemical compound AMC using the same proportion of reaction stopper as was used for terminating the enzyme reaction. viz. 4.0:0.32, v/v.

Net fluorescence for each substrate concentration at every time point was calculated by subtracting the zero-time fluorescence from the gross fluorescence observed at that time point. The net fluorescences were then used to draw time-dependent activity curves. The potential APA was calculated as $V_{\max }$ of releasing rate of AMC in per unit volume of waters in unit time (nM $\left.\mathrm{AMC} \mathrm{h}^{-1}\right)$ using Hanes equation $\left(S / V=K_{\mathrm{m}} / V_{\max }+\right.$ $S / V_{\max }$ ), a linearized form of the Michaelis-Menten equation (Dowd \& Riggs 1965), where $S=$ substrate concentration, $V=$ velocity of enzymatic reaction $(\mu \mathrm{M}$ $\left.\mathrm{h}^{-1}\right), K_{\mathrm{m}}=$ half saturation constant $(\mu \mathrm{M})$, and $V_{\max }=$ maximum uptake velocity $\left(\mu \mathrm{M} \mathrm{h}^{-1}\right)$. The linearized form of the Michaelis-Menten equation has been widely used by microbial ecologists to calculate the potential hydrolytic activities in natural conditions (Robinson 1985).

Statistical analyses. Simple linear regression was used to investigate the general correlations between APA and environmental factors for the surface and the bottom waters, separately. The data of bacterial properties, including APA, bacterial abundances, and percell activities (APA/bacterial abundance), were naturallog transformed to equalize the variance. Furthermore, in order to discern the environmental factors which might have regulated the APA on a short-term basis or during a particular situation, correlation analyses were performed separately for 2 subgroups of the composite data of surface and bottom waters (henceforth referred to as water column) viz. when water column was (1) thermally homogeneous (October to March), and (2) thermally stratified (May to September). Vertical variabilities in APA, bacterial abundance, and per-cell activity were calculated as ratios of surface value/bottom value (vertical variability index). 


\section{RESULTS}

The temperature showed strong seasonality in the inlet and varied from less than $11.5^{\circ} \mathrm{C}$ in February to more than $28.5^{\circ} \mathrm{C}$ in September (Fig. 2A). Thermal stratification became evident from late spring (May) and lasted until the late summer (until September). On extreme days, the temperature of bottom water was more than $3.0^{\circ} \mathrm{C}$ lower than that of surface water. Destratification of the water column took place during the early autumn (mid-September) after which the water column became thermally homogeneous until early spring (mid-March). The DO contents of surface and bottom waters were similar when the water column was thermally homogeneous, but considerable differences were observed during the period of stratification (May to September; Fig. 2A,B). Generally, DO of surface water stayed above $4 \mathrm{mg} \mathrm{l}^{-1}$ for most of the year and did not show much seasonal variation. In contrast,

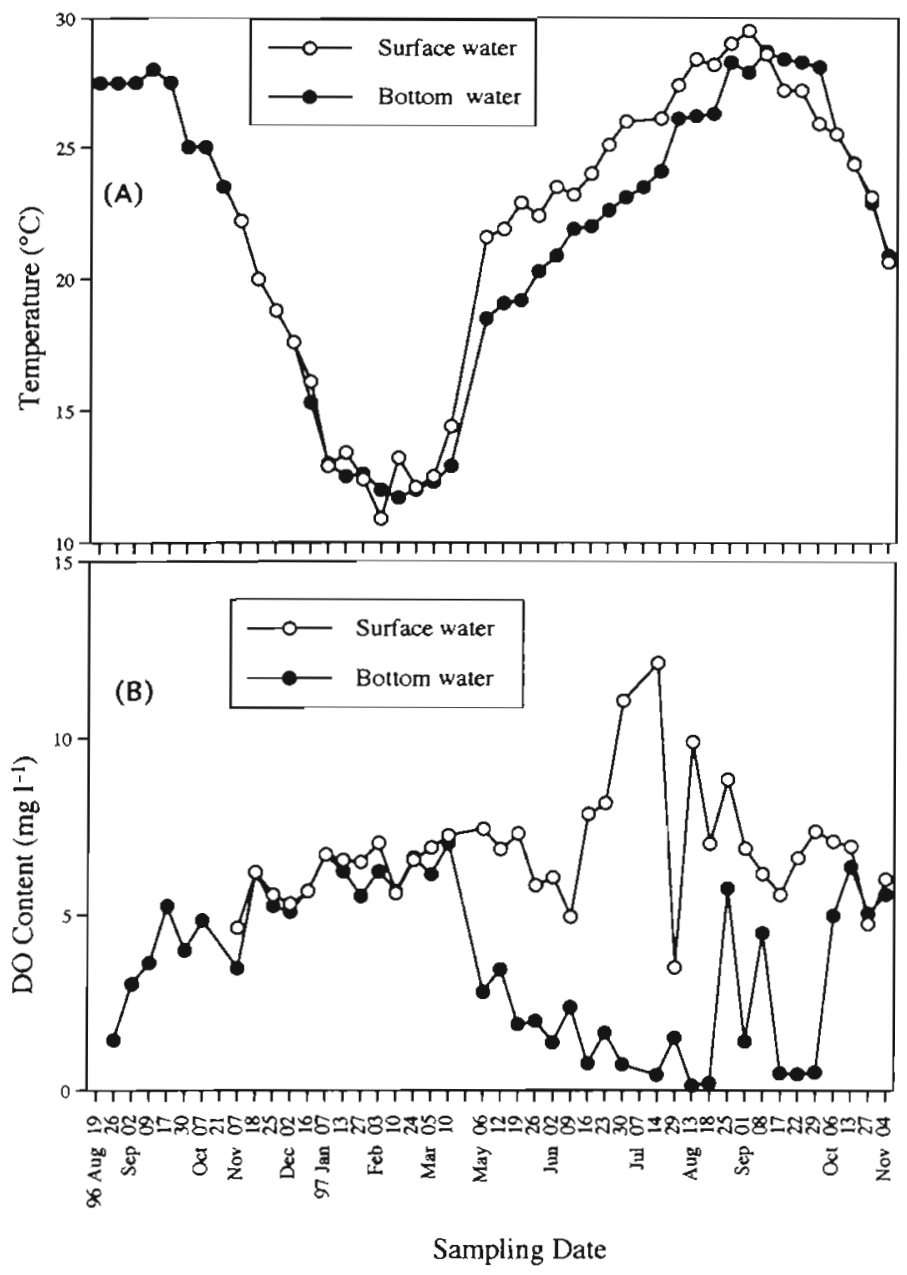

Fig. 2. Temporal fluctuations in (A) temperature, and (B) dissolved oxygen (DO) contents of surface and bottom waters at the sampling site bottom water exhibited a noticeable seasonal variation. It changed from a minimal of $0.17 \mathrm{mg} \mathrm{l}^{-1}$ in late summer (August) to considerably higher values ranging between 4 and $7 \mathrm{mg} \mathrm{l}^{-1}$ during late fall to winter (October to March). Temporal variations in nutritional parameters of surface and bottom waters including TDN, DIN, DON, and DIP are presented in Fig. 3. For all of these parameters, the extent of seasonality was more prominent in the case of bottom water, with relatively higher values during the summer. Furthermore, vertical variabilities in these parameters quite closely corresponded to the thermal stratification, in the sense that when the water column was mixed, nutritional contents of surface and bottom waters were similar (October to March), but when the water column became stratified, vertical variabilities became quite obvious (May to September) with bottom water exhibiting considerably higher nutrient contents, especially of DIN and DIP.

The bacterial abundances of both (surface and bottom) waters showed quite similar seasonal patterns, although slightly higher abundance was noticed in the case of surface water, especially when water column was stratified (Fig. 4). It ranged between 2.2 and $6.6 \times$ $10^{6}$ bacterial cells $\mathrm{ml}^{-1}$ for surface water, and 2.1 and $5.1 \times 10^{6}$ cells $\mathrm{ml}^{-1}$ for bottom water, thus varying about 2.5 to 3 times for both waters during the study period. In contrast, the magnitudes of seasonal variations in the APA of surface and bottom waters were quite different (Fig. 5). While the surface water showed pronounced seasonal variations with a minimum of $23 \mathrm{nM}$ $\mathrm{AMC} \mathrm{h}^{-1}$ in the late winter (February) and a maximum of $1017 \mathrm{nM} \mathrm{AMC} \mathrm{h}^{-1}$ in summer (August), the bottom water exhibited only limited seasonality, and the minimum of $21 \mathrm{nM} \mathrm{AMC} \mathrm{h}^{-1}$ observed during late winter (February) increased to reach a maximum only of $270 \mathrm{nM}$ AMC $\mathrm{h}^{-1}$ in late summer to early autumn (August to September). It is important to note that both waters possessed similar APA when the water column was thermally homogeneous (October to March) but considerable differences (bottom water exhibiting considerably lower APA) were apparent when the water column was stratified (May to September).

The range values for APA, $K_{m}+S$, and other important physicochemical parameters such as temperature, DO, salinity, $\mathrm{pH}$, bacterial abundance, chl $a$, and nutritional parameters including DIN, DON, TDN and DIP for both surface and bottom waters are presented in Table 1.

\section{DISCUSSION}

Uranouchi Inlet, apart from being a eutrophic ecosystem, demonstrated typical seasonal stratification (May 


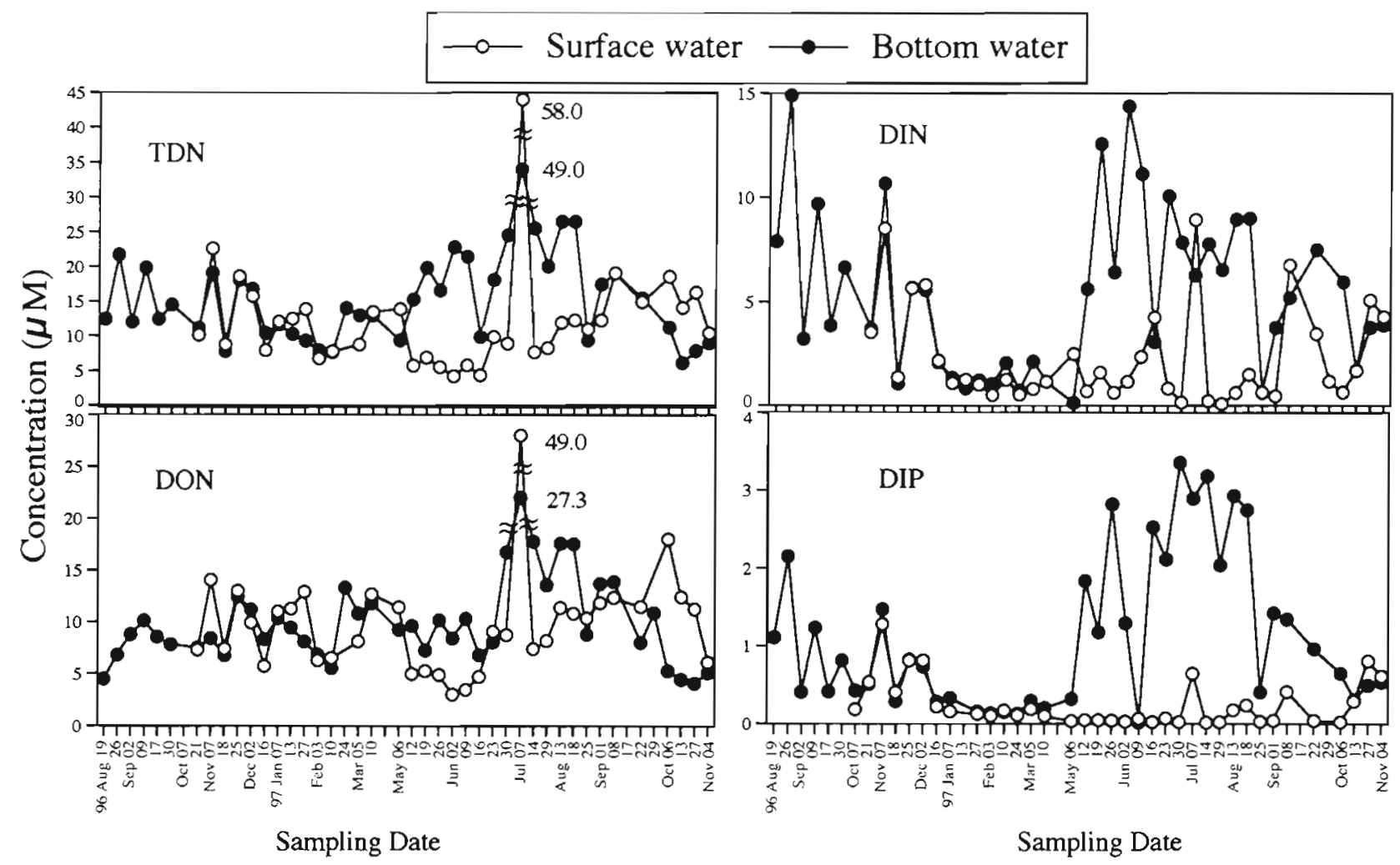

Fig. 3. Temporal variations in different forms of nitrogen and inorganic phosphorus contents in surface and bottom waters at the sampling site

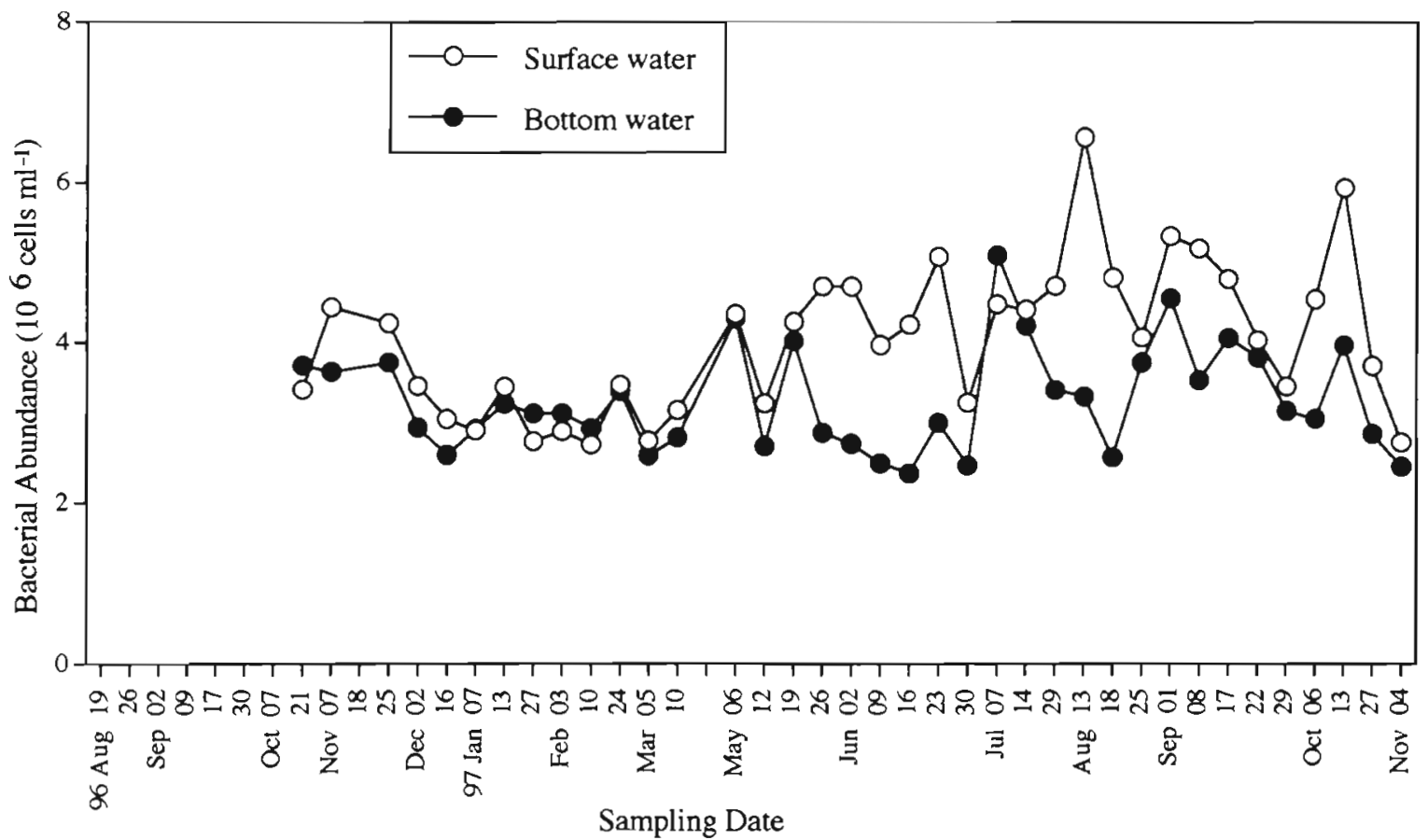

Fig. 4. Temporal variations in bacterial abundance of surface and bottom waters at the sampling site 


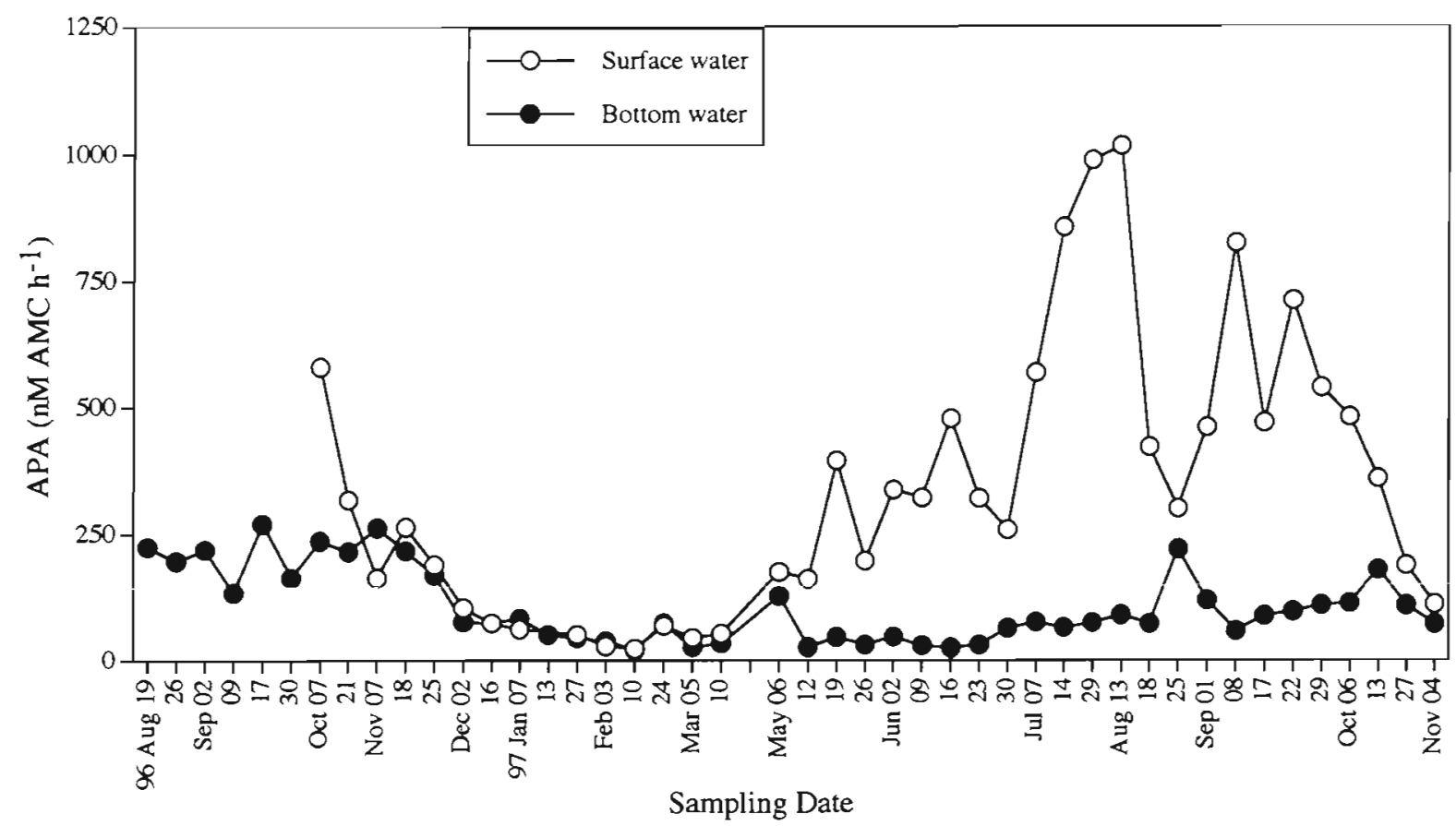

Fig. 5. Temporal variations in the potential aminopeptidase activity (APA) in surface and bottom waters during the study period

to September) during the study period (1996-1997), resulting in compartmentalization of surface and bottom waters in relation to ecological parameters such as temperature, DO, nutritional contents, and bacterial abundance (Figs. 1 to 4 ). It therefore presented a useful system, considering our objectives, for investigating correlations between the APA and ecological parameters on an annual basis and as influenced by changes in the water column structure. On an annual basis, APA of surface and bottom waters in Uranouchi Inlet showed highly significant correlation $(p<0.001)$ with temperature (Fig. 6A,B), and bacterial abundances of

Table 1. Range values of aminopeptidase activities, the $K_{\mathrm{m}}+S$, and important physicochemical parameters for surface and bottom waters at the sampling site

\begin{tabular}{|c|c|c|}
\hline Estimated parameters & Surface water & Bottom water \\
\hline Aminopeptidase activity ( $\mathrm{nM} A M C \mathrm{~h}^{-1}$ ) & $23.15-1016.89$ & $21.06-269.63$ \\
\hline$K_{\mathrm{m}}+S(\mu \mathrm{M})$ & $10.83-43.35$ & $9.07-57.63$ \\
\hline Bacterial abundance $\left(10^{6}\right.$ cells $\left.\mathrm{ml}^{-1}\right)$ & $2.21-6.57$ & $2.10-5.09$ \\
\hline 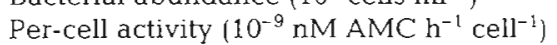 & $10.46-209.83$ & $8.86-88.74$ \\
\hline Temperature $\left({ }^{\circ} \mathrm{C}\right)$ & $10.9-29.5$ & $11.7-28.7$ \\
\hline Dissolved oxygen $\left(\mathrm{mg} \mathrm{l}^{-t}\right)$ & $4.63-12.50$ & $0.17-7.02$ \\
\hline $\mathrm{pH}$ & $7.86-9.76$ & $7.72-9.81$ \\
\hline Salinity (psu) & $26.25-36.10$ & $31.40-36.40$ \\
\hline Chlorophyll a $\left(\mu \mathrm{g}^{-1}\right)$ & $2.34-61.40$ & $0.21-5.05$ \\
\hline Total dissolved nitrogen $(\mu \mathrm{M})$ & $4.18-57.98$ & $6.15-33.61$ \\
\hline Dissolved inorganic nitrogen $(\mu M)$ & $0.08-8.94$ & $0.15-14.89$ \\
\hline Dissolved organic nitrogen $(\mu \mathrm{M})$ & $3.02-49.04$ & $4.07-27.32$ \\
\hline Dissolved inorganic phosphate $(\mu \mathrm{M})$ & $0.01-1.28$ & $0.02-3.36$ \\
\hline
\end{tabular}

respective waters (Fig. 6C,D). Such observations are in agreement with previous studies, such as Lovejoy et al. (1996) and Goosen et al. (1997) who demonstrated temperature as one of the most influential environmental factors explaining the variation in the bacterial activities, and Wheeler \& Kirchman (1986) who reported that protein or peptides are important sources of nutrition and growth for marine bacteria. It is noteworthy that these correlations were stronger and that the slopes of regression curves were higher for the surface water (Fig. 6A: $\mathrm{r}=0.90$, slope $=0.17$; Fig. $6 \mathrm{C}: \mathrm{r}=0.80$, slope $=3.52$ ) compared to those for bottom water (Fig. 6B: $r=0.55$, slope $=0.07$; Fig, 6C: $r=0.54$, slope $=1.17$ ). These differences are consistent with the 2 ecological conditions in the 2 layers as a consequence of summer thermal stratification. Interestingly, on an annual basis, APA did not show any correlation ( $p>0.05$ ) with DO contents for both waters (Figs. not shown). However, taking into account the empirical fact that considerably lower values of APA were observed in bottom water which usually possessed low DO contents, we consider that the ecological 


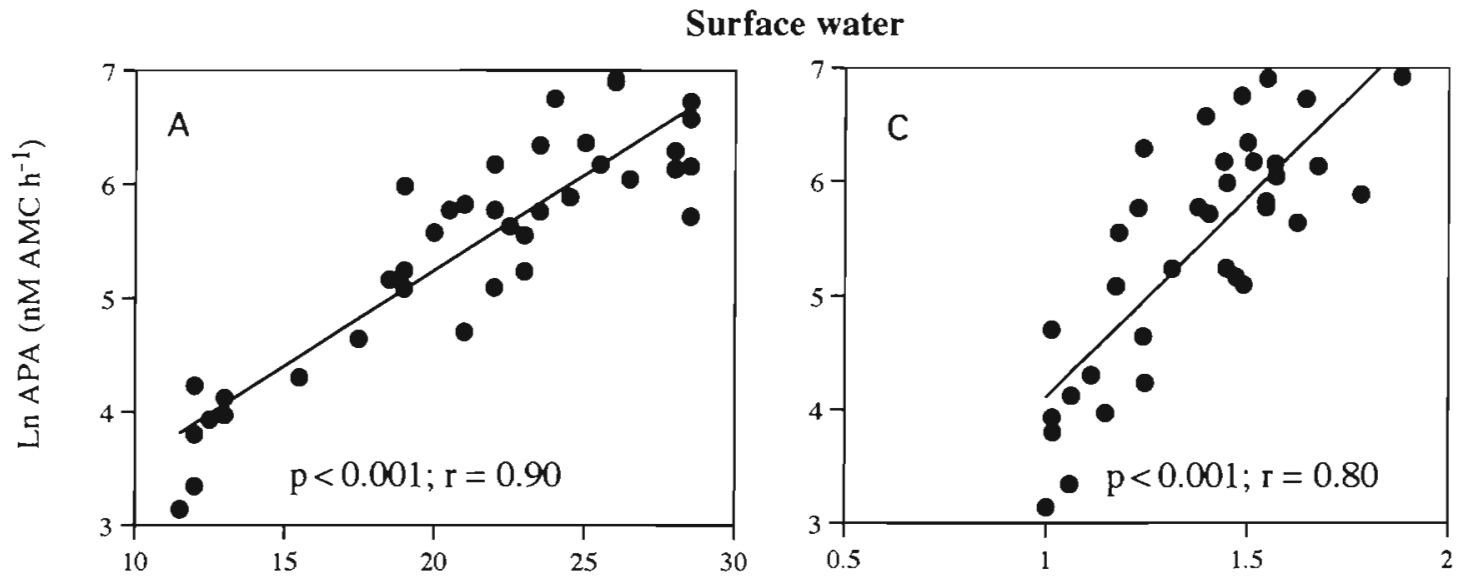

Bottom water
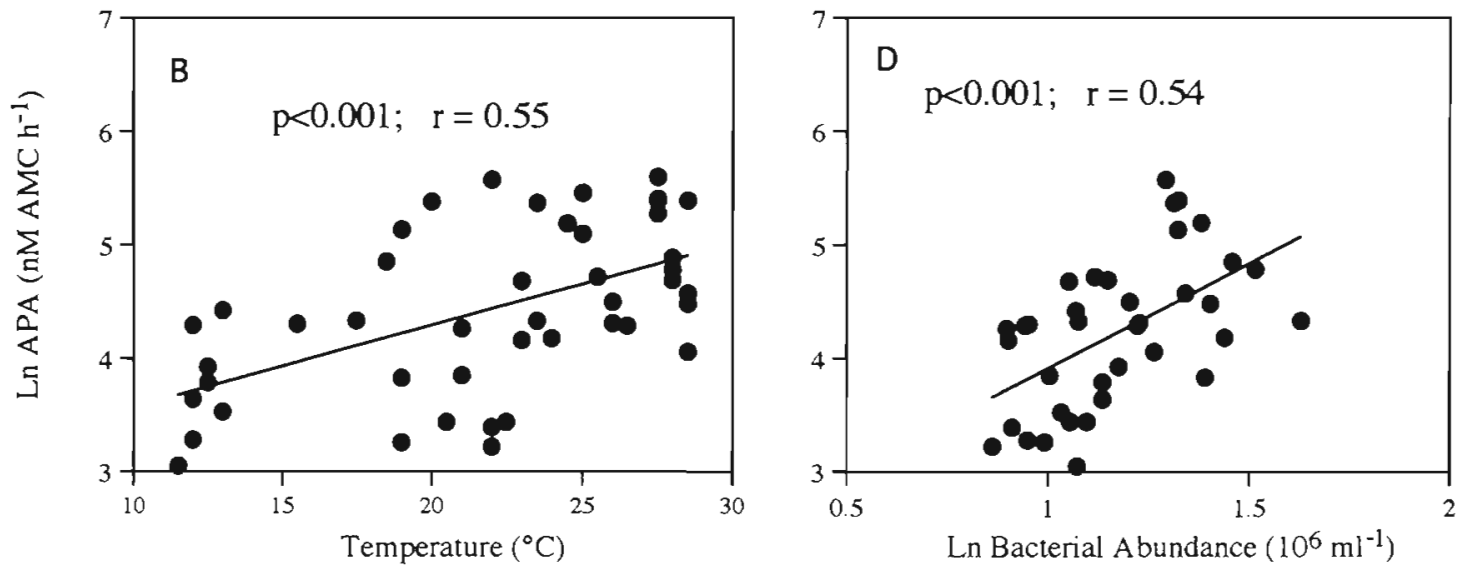

Fig. 6. Correlations between natural $\log (\mathrm{Ln})$ transformed APA and temperature, and bacterial abundance for (A,C) surface and $(B, D)$ bottom waters

basis behind the lack of correlation between DO and APA may be quite different for surface water than for bottom water. In the case of surface water, DO may not be a limiting factor as it is in abundant supply (>4 mg $\mathrm{l}^{-1}$ ) throughout the year. But, in the case of bottom water, where DO might have been in limited supply during the summer, the situation is quite complex owing to the counter-effects of temperature. For instance, decreasing DO contents of bottom water coincided with increasing temperature and consistently high DO contents coincided with considerably lower $\left(<16\right.$ to $\left.17^{\circ} \mathrm{C}\right)$ temperature, and vice-versa. Therefore, no effective increase or decrease in APA could be observed with those in DO contents.

As concerns annual correlations with other environmental factors, APA did not show any correlation $(p>0.05)$ with chl a contents in the case of bottom water, and only marginally significant correlation $(\mathrm{p}<0.05 ; \mathrm{r}=0.44)$ in the case of surface water. Such low profile relationships are logical possibilities con- sidering the fact that the study site was a heterotrophic ecosystem in which allochthonous organic inputs form the major source of nutrients rather than the exudates from phytoplankton. Poor correlations between chlorophyll and bacterial activity in eutrophic ecosystems have been reported by other researchers (Hoch \& Kirchman 1993, Shiah \& Ducklow 1994). Similarly, APA did not show any correlation $(p>0.05)$ with nutritional parameters including TDN, DIN, DON and DIP contents of either of the waters, indicating that the activity is not nutrient limited. It may be of relevance to point out that while some studies have reported organic matter input being an important controlling factor of heterotrophic activity (Hollibaugh \& Azam 1983, Wright \& Coffin 1983), it is also agreed that in coastal and estuarine areas, factors other than substrate supply may regulate the activity (Shiah \& Ducklow 1994). The latter was found to be the case at the present study site. We do not have any data about the qualitative composition of DON and hence are unable 


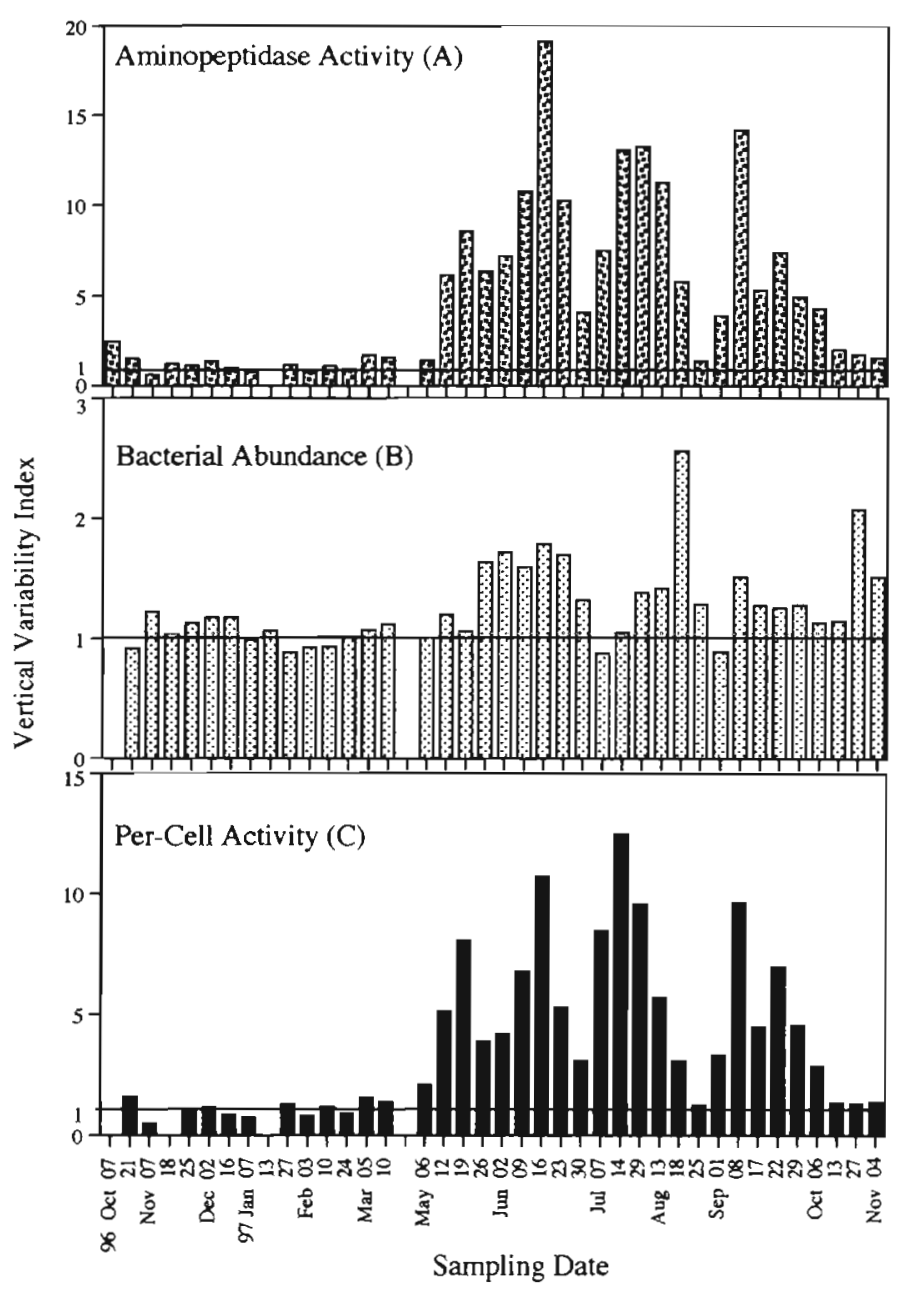

Fig. 7 Vertical variability index for (A) aminopeptidase activities, (B) bacterial abundances, and (C) per-cell activities during the study period

to comprehend the qualitative impact of organic matter composition. It was also interesting to note that APA of both waters showed negative correlations with salinity of the respective waters $(p<0.001 ; r=-0.78$ for surface water and $p<0.01 ; r=-0.39$ for bottom water) (Figs. not shown). Such correlations may perhaps be due to periodic intrusions of offshore waters possessing high salinity and low bacterial abundance or activity and/or entrance of occasional runoffs possessing low salinity and high bacterial abundance or activity from the surrounding areas into the study site. Such speculations may be justified by marginally negative correlations between bacterial abundance and salinity $(\mathrm{p}<0.001 ; \mathrm{r}=-0.54$ for surface water and $\mathrm{p}<0.05$; $r=-0.27$ for bottom water), and highly significant negative correlation between the bacterial efficiency (percell activity) and salinity, especially in the case of surface water ( $\mathrm{p}<0.001 ; \mathrm{r}=-0.80$ ) (Figs. not shown).
Temporal patterns of APA in both waters (Fig. 5) indicate that in the post-winter period when the water column became stratified, APA of surface water increased considerably with increasing temperature whereas bottom water continued to possess considerably lower APA. Previous studies (Ducklow \& Carlson 1992, Shiah \& Ducklow 1994) have also reported considerably lower heterotrophic activities in bottom waters compared to surface waters in other stratified environments. It is also important to note that vertical variabilities in APA (Fig. 7A) (up to 20 times) were much greater than those in bacterial abundances (Fig. 7B) (only 2 times). We assume that vertical variabilities in APA were probably due more to differences in bacterial efficiencies, i.e. per-cell activities (a derived parameter; see 'Materiais and methods') than to the bacterial abundances of the waters. During the period of stratification, per-cell activities of surface water bacteria were as much as 12 times higher than those of bottom water (Fig. 7C).

We hypothesize that the vertical variabilities in APA during stratified conditions should primarily correspond to the vertical variabilities in some of the ecological parameters which were critical for the APA, and hence, conducting the correlation analyses between the composite data of APA and environmental factors of surface and bottom waters during this period would help us in understanding the key regulating factors. We also considered that the critical factor or factors which regulated the APA as a whole during stratified conditions may not be the same when the water column became mixed due to 2 quite different ecological situations. To investigate the specific regulating factors in these 2 specific situations, we divided the composite data of surface and bottom waters (water column) into 2 subgroups as mentioned in 'Materials and methods' viz. when water column was (1) thermally homogeneous (October to March), and (2) stratified (May to September), and conducted correlation analyses separately. When the water column was homogeneous, APA showed highly significant correlations with temperature $(p<0.001 ; r=0.87$, Fig. $8 A$ ), but no correlation with DO content ( $p>0.05$, Fig. $8 B$ ). Furthermore, APA also showed marginally significant correlation with DIN ( $p<0.05 ; r=0.43)$ or DIP contents ( $p<0.05 ; r=0.40)$, and no correlation with DON content $(p>0.05)$ (Figs. not shown). Conversely, during the stratified period, APA showed only a weak correlation with temperature ( $p<0.05 ; x=0.32$, Fig. 9A) but a highly significant correlation with DO ( $p<0.001$; $r=0.76$, Fig. 9B). Furthermore, APA showed negative correlations $(\mathrm{p}<0.001)$ with DIN $(\mathrm{r}=-0.61)$ or DIP contents $(r=-0.70)$, and no correlation with DON content ( $p>0.05)$ (Figs. not shown). It might also be of interest to point out that there was no qualitative shift in the 

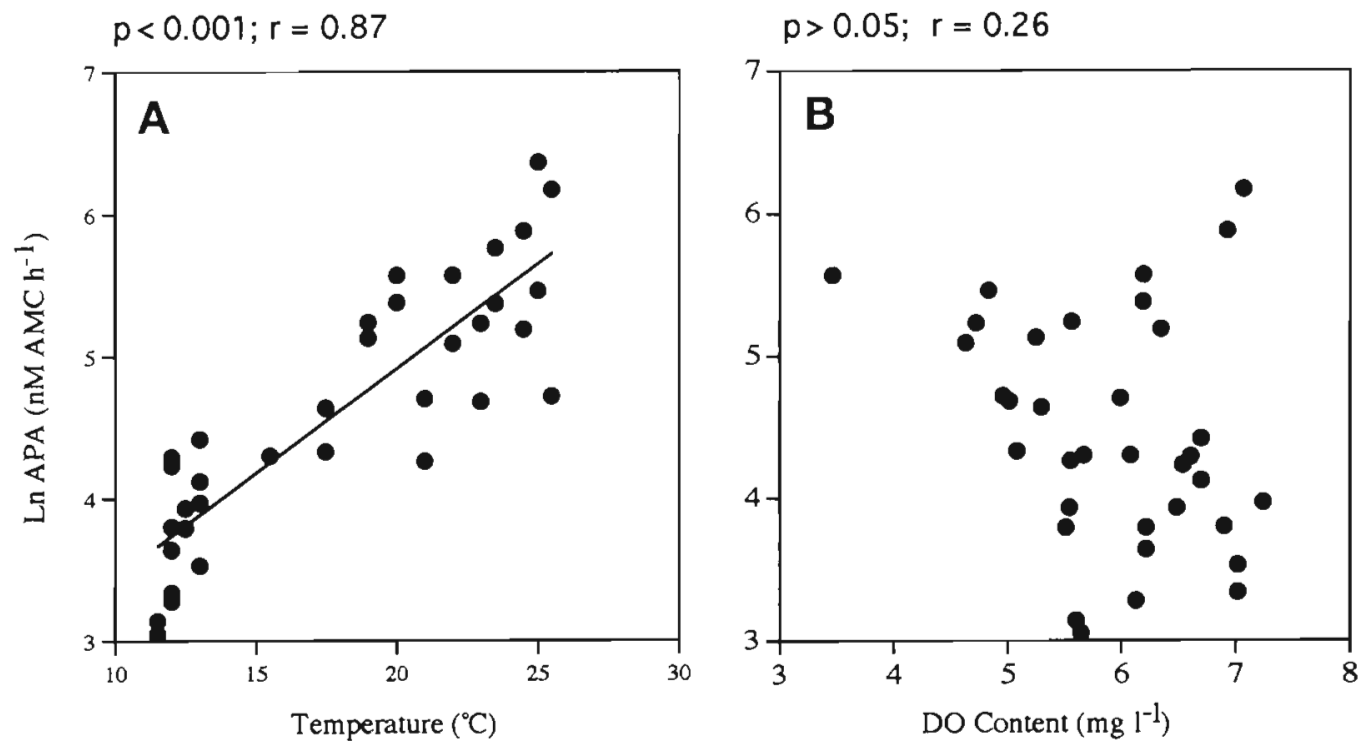

Fig. 8. Correlations between Ln APA and (A) temperature, and (B) DO content when water column was mixed

correlations between the APA and bacterial abundance or salinity during homogeneous and stratified water columns. For instance, bacterial abundance had a significant $(p<0.001)$, and equally strong, correlation with APA in both situations $(r=0.73$ during stratified and $r=0.74$ during homogeneous period) (Figs. not shown).

The above-mentioned contrasting correlations of temperature, DO, and inorganic nutrient contents during mixed and stratified water columns suggest that there may be a qualitative shift in the roles of these factors, regarding the regulation of the APA, depending on the changes in the water column structure as affected by thermal stratification. For example, during the period when the water column was mixed, temperature seemed to play the most dominant role in regulating the APA with DO not playing an important role, probably as a consequence of the fact that mixed water column coincided with relatively low temperature and high DO regimes. Shiah \& Ducklow (1994), and Lovejoy et al. (1996) have reported temperature as a dominant regulating factor for heterotrophic
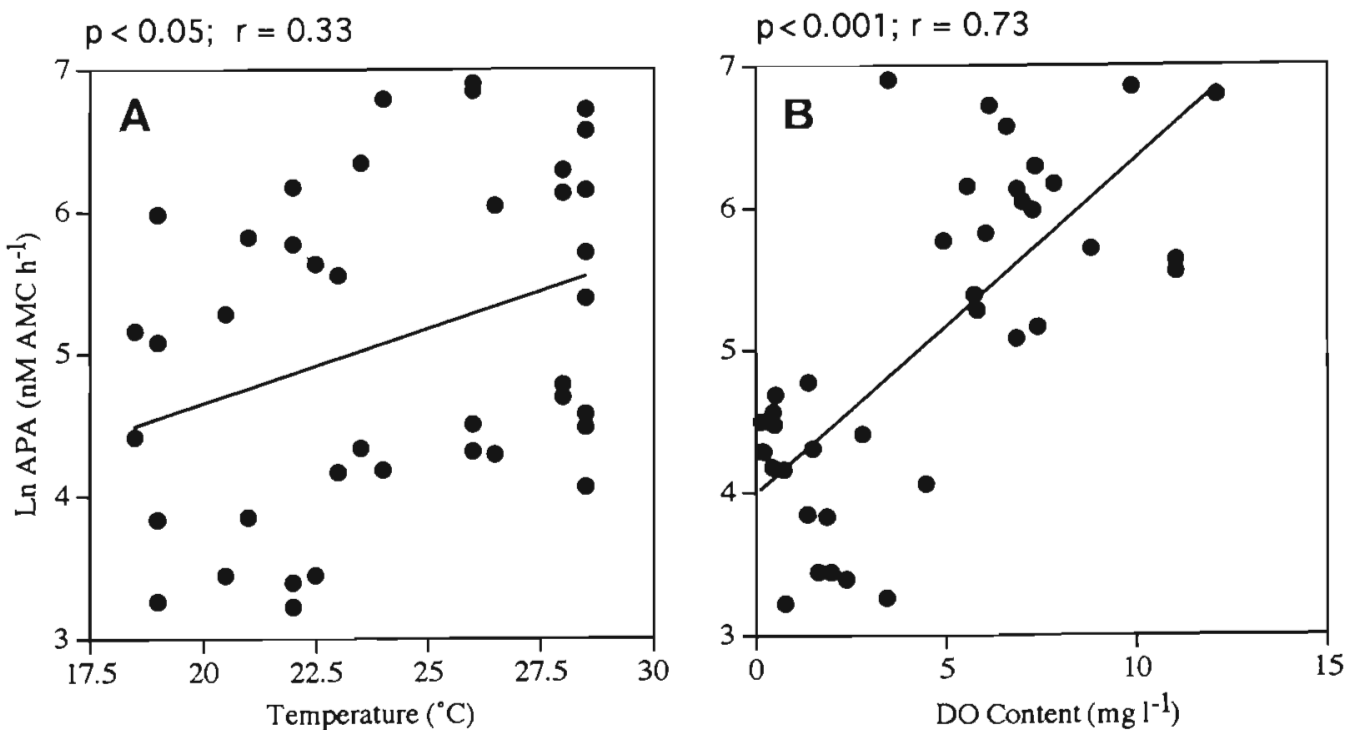

Fig. 9. Correlations between Ln APA and (A) temperature, and (B) DO content when water column was thermally stratified 
activity especially in a low water situation. Furthermore, relatively low DIN or DIP contents in the water column during this period may have facilitated APA. Wouters \& Bieysman (1977) observed maximal proteinase production by bacteria grown in chemostat under conditions of nitrogen limitation. In the present study, stratification coincided with a relatively higher temperature regime and hence temperature was no more a prime limiting factor; instead, factors like DO, DIN or DIP contents which showed considerable vertical variabilities seem to be the important regulating factors. It may be prudent to point out that these correlations are significant due mainly to the difference in the APA of surface water which possessed high DO and low DIN or DIP content, and bottom water which possessed low DO and high DIN or DIP content. The correlation analyses indicate that the difference in APA is mostly a result of contrasting DO (lower), DIN or DIP (higher) contents of the bottom water compared to those of surface water. It is beyond the scope of the present study however, to predict the exact mechanism for regulation of APA. For example, it is difficult to discern whether lower activities in bottom water were a result of sub-optimal oxic conditions for aerobic microbial communities residing in bottom water (Shiah \& Ducklow 1994), or due to gradual domination of microaerophiles or anaerobs, which are known to possess lower activities compared to their aerobic counterparts (Graves et al 1991) during periods of low DO. Nevertheless, the latter case seems to be a greater possibility considering the fact that during the late summer (stratified condition), for bottom water, no correlation between APA and DO content was observed ( $p>0.05$, data not shown), and even occasional increases in DO contents coincided with lower APA. Such an inhibitory effect of DO may indicate that during periods of consistently low DO, microaerophilic bacteria might have become the abundant microbial group which prefers lower oxygen content. Furthermore, it could also be that higher concentrations of DIN or DIP contents in bottom water which are readily utilizable substrates repressed the secretion of extracellular enzymes. Chróst (1991) demonstrated that supplementation of lake water samples with inorganic nitrogen significantly inhibited the $V_{\max }$ of leu-amp enzyme reaction. Conversely, it is also difficult to discern whether higher activities in surface water during summer are due mostly to the fact that more active bacteria usually occupy the oxycline layers of the water column (Hastings et al. 1998) or to favorable environmental factors such as a combination of optimum DO and temperature and a relatively inorganic nutrient-deficient environment which might have enhanced the bacterial production rate or secretion of extracellular enzymes.
This study emphasizes that for an ecosystem which experiences seasonal stratification and considerable alterations in physicochemical parameters within a year, statistical analyses performed after treatment of all the data points equally may mask the impacts of certain environmental factors which might have been the controlling factors only during a specific period of the year. For that matter, in this inlet, the temperature during October to March, and the DO or the inorganic nutrient contents during the May to September period seem to play a critical role in regulating the APA. Thus, it became evident that for an ecosystem which undergoes thermal stratification, the physicochemical parameters which play a critical role in regulating the activities may change with the season or depending on water column structure. This information may be of considerable importance from the view point of formulating appropriate bioremediation strategies for enhancing the heterotrophic processes, especially in localized context such as below fish cages. For instance, addition of psychrophilic bacteria (attached to some substrate) which are capable of performing high metabolic activities even at lower temperature may have the potential to accelerate the utilization or recycling of protein in the water column during winter by utilizing abundantly available DO.

Acknowledgements. The authors thank Dr M. Adachi for his comments related to the study, $\mathrm{Mr} \mathrm{H}$. Nishitani for his help in analyses, and Mr R. Nakajima and the staff of the marine biological research center Usa (Japan) for their help during sampling. This study was supported in part by a grant-in-aid (Bio Renaissance Program) from the Ministry of Agriculture, Forestry and Fisheries (BRP-98-II-B-1).

\section{LITERATURE CITED}

APHA (1985) Chlorophyll. In: Franson MAH (ed) Standard methods for the examination of waste water, 15th edn American Public Health Association, Washington, DC. p 1067-1072

Chróst RJ (1990) Microbial ectoenzymes in aquatic environments. In: Overbeck $J$, Chróst RJ (eds) Aquatic microbial ecology: biochemical and molecular approaches. Springer Verlag, New York, p 47-78

Chróst RJ (1991) Environmental control of the synthesis and activity of aquatic microbial ectoenzymes. In: Chróst RJ (ed) Microbial enzymes in aquatic environments. Springer Verlag, New York, p 29-59

Dowd JE, Riggs DS (1965) A comparison of estimates of Michaelis-Menten kinetic constants from various linear transformations. J Biol Chem 240:863-869

Ducklow HW, Carlson GA (1992) Oceanic bacterial production. In: Marshall KC (ed) Advances in microbial ecology, Vol 12. Plenum Press, New York, p 113-181

Fukami K, Meier B, Overbeck J (1991a) Vertical and temporal changes in bacterial production and its consumption by heterotrophic nanoflagellates in a north German eutrophic lake. Arch Hydrobiol 122:129-145 
Fukami K, Nishijima T, Murata H, Doi S, Hata Y (1991b) Distribution of bacteria influential on the development and the decay of Gymnodinium nagasakiense red tide and their effects on algal growth. Nippon Suisan Gakkaishi $57(12): 2321-2326$

Fukami K, Murata N, Morio Y, Nishijima T (1996) Distribution of heterotrophic nanoflagellates and their importance as the bacterial consumer in a eutrophic coastal sea water J Oceanogr 52:399-407

Goldman JC, Taylor CD, Gilbert PM (1981) Nonlinear timecourse uptake of carbon and ammonium by marine phytoplankton. Mar Ecol Prog Ser 6:137-148

Goosen NK, Rijiswijk PV, Kromkamp J, Peene J (1997) Regulation of annual variation in heterotrophic bacterial production in the Schelde estuary (SW Netherlands). Aquat Microb Ecol 12:223-232

Gowen RJ, Rosenthal H, Mäkinen T, Ezzi I (1990) Environmental impact of aquaculture activities. In: De Pauw $\mathrm{N}$, Wilkins $N$ (eds) Aquaculture Europe' 89-Business Joins Science. European Aquaculture Society, Spec Publ No. 12. Bredene, p 1071-1080

Graves DA, Lang GA, Leavitt ME (1991) Respirometric analysis of biodegradation of organic contaminants in soil and water. Appl Biochem Biotech 28-29:813-826

Hastings RC, Saunders JR, Hall GH, Pickup RW, McCarthy AJ (1998) Application of molecular biological techniques to a seasonal study of ammonia oxidation in a eutrophic freshwater lake. Appl Environ Microbiol 64:3674-3682

Hoch MP, Kirchman DL (1993) Seasonal and inter annual variability in bacterial production and biomass in a temperate estuary. Mar Ecol Prog Ser 98:283-295

Hollibaugh JT, Azam F (1983) Microbial degradation of dissolved proteins in sea water. Limnol Oceanogr 28: $1104-1116$

Hoppe HG (1983) Significance of exoenzymatic activities in the ecology of brackishwater: measurements by means of methylumbelliferyl substrates. Mar Ecol Prog Ser 11: 299-308

Hoppe HG, Kim SJ, Gocke K (1988) Microbial decomposition in aquatic environments: combined processes of extracellular enzyme activity and substrate uptake. Appl Environ Microbiol 54:784-790

Jackson C, Foreman CM, Sinsabaugh RL (1995) Microbial enzyme activities as indicators of organic matter processing rates in a Lake Erie coastal wetland. Freshw Biol 34: $329-342$

Johnsen RI, Grahl-Nielsen O, Lunestad BT (1993) Environmental distribution of organic waste from a marine fish farm. Aquaculture 118:229-244

King GM (1986) Characterization of fl-glucosidase activity in intertidal marine sediments. Appl Environ Microbiol 51: $373-380$

Lovejoy C, Legendre L, Klein B, Tremblay J, Ingram RG, Therriault J (1996) Bacterial activity during early winter mixing (Gulf of St. Lawrence, Canada). Aquat Microb Ecol 10:1-13

McCaig AE, Phillips CJ, Stephen JR, Kowalchuk GA, Harvey SM, Herbert RA, Embley TM, Prosser JI (1999) Nitrogen

Editorial responsibility: Farooq Azam,

La Jolla, California, USA cycling and community structure of proteobacterial $\beta$-subgroup ammonia oxidizing bacteria within polluted marine fish farm sediments. Appl Environ Microbiol 65:213-220

Meyer-Reil LA (1990) Microorganisms in marine sediments: considerations concerning activity measurements. Arch Hydrobiol Beih Ergeb Limnol 34:1-6

Meyer-Reil LA (1991) Ecological aspects of enzymatic activity in marine sediments. In: Chróst RJ (ed) Microbial enzymes in aquatic environments. Springer Verlag, New York p $84-95$

Münster U, Chróst RJ (1990) Origin, composition and microbial utilization of dissolved organic matter. In: Overbeck J, Chróst RJ (eds) Aquatic microbial ecology: biochemical and molecular approaches. Springer Verlag, New York, p 8-46

Poremba K (1995) Hydrolytic activity in deep-sea sediments. FEMS Microbiol Ecol 16:213-222

Porter KG, Feig YS (1980) The use of DAPI for identifying and counting aquatic microflora. Limnol Oceanogr 25:943-948

Robinson JA (1985) Determining microbial kinetic parameters using nonlinear regression analysis. In: Marshall KC (ed) Advances in microbial ecology, Vol 8. Plenum Press, New York, p 61-114

Romankevich EA (1984) Geochemistry of organic matter in the ocean. Springer Verlag, New York

Rosso AL, Azam F (1987) Proteolytic activity in coastal oceanic waters: depth distribution and relationship to bacterial populations. Mar Ecol Prog Ser 41:231-240

Saifuku K, Sekine T, Namihisa T, Takahashi T, Kanaoka Y (1978) A novel fluorometric ultramicro determination of serum leucine aminopeptidase using a coumarine derivative. Clin Chim Acta 84:85-91

Sepers ABJ (1977) The utilization of dissolved organic compounds in aquatic environments. Hydrobiologia 52:39-54

Shiah F, Ducklow HW (1994) Temperature regulation of heterotrophic bacterioplankton abundance, production, and specific growth rate in Chesapeake Bay. Limnol Oceanogr 39:1243-1258

Shpigel M, Neori A, Popper DM, Gordin H (1993) A proposed model for environmentally clean land-based culture of fish, bivalves and sea weeds. Aquaculture 117:115-128

Somville M, Billen G (1983) A method for determining exoproteolytic activity in natural waters. Limnol Oceanogr 28 : 190-193

Venrick EL, Beers JR, Heinbokel JF (1977) Possible consequences of containing microplankton for physiological rate measurements. J Exp Mar Biol Ecol 26:55-76

Weston DP (1990) Quantitative examination of macrobenthic community changes along and organic enrichment gradient. Mar Ecol Prog Ser 61:233-244

Wheeler PA, Kirchman DL (1986) Utilization of inorganic and organic nitrogen by bacteria in marine systems. Limnol Oceanogr 31:998-1009

Wouters JTM, Bieysman PJ (1977) Production of some exocellular enzymes by bacillus licheniformis $749 / \mathrm{C}$ in chemostat cultures. Fed Eur Microb Soc Lett 1:109-112

Wright RT, Coffin RB (1983) Planktonic bacteria in estuaries and coastal waters of northern Massachusetts: spatial and temporal distribution. Mar Ecol Prog Ser 11:205-216

Submitted: November 5, 1998; Accepted: September 21, 1999 Proofs received from author(s): February 16, 2000 